\title{
EXPERIMENTAL STUDY ON EFFECTS OF STABILIZATION OF CLAYEY SOIL USING COPPER SLAG AND GGBS
}

\author{
M.Kavisri ${ }^{1, *}$, P.Senthilkumar ${ }^{2}$, M. S. Gurukumar ${ }^{3}$ \\ and Karunian J. Pushparaj ${ }^{4}$ \\ ${ }^{1}$ Department of Civil Engineering, Sathyabama University, Chennai-119, Tamilnadu, India \\ ${ }^{2}$ Department of Chemical Engineering, Sathyabama University, Chennai-119, Tamilnadu, India \\ ${ }^{3,4}$ Department of Civil Engineering, Sathyabama University, Chennai-119, Tamilnadu, India \\ *E-mail:kavisrimanikannan1985@gmail.com
}

ABSTRACT

This paper helps in identifying the utilization of industrial by-product copper slag and Ground Granulated Blast Furnace Slag(GGBS) as a stabilizing agent in the expansive soil with high swelling property causing severe damage to the building built on it and this study is used for identifying the optimum percentage of copper slag and GGBS for increasing the strength of clayey soil.Three different fractions namely 10\%, 20\%, 30\% of the copper slag and GGBS accordingly various tests for determine the engineering properties of soil like Maximum Dry Density (MDD), Optimum Moisture Content (OMC) and California Bearing Ratio (CBR) and Unconfined Compressive Strength (UCC) are done and the results are compared with the Indian Standards for design requirement of sub-grade and flexible pavement. The result shows that $70 \%$ clay soil and $30 \%$ copper slag and GGBS is the compatible stabilization ratio which increases all desirable sub-grade requirements.

Keywords: Copper slag, GGBS, Optimum Moisture Content, Maximum Dry Density, Unconfined Compressive Strength.

(C) RASĀYAN. All rights reserved

\section{INTRODUCTION}

The soil is a complex, heterogeneous, uncontrollable and material having huge varying properties which not only differs from place to place but also by various depths. It is not easily transportable like the other construction materials such as steel, concrete and also its engineering properties depend on the environment in which it is present. ${ }^{1,2}$ Soil plays the major role on a construction site. Its properties such as bearing capacity, shrinkage limit, porosity, bulk density, the degree of saturation, plastic limit, water content etc., are some of the major properties which affect the construction of the building. In India, Soil stabilization of the modern era started around the mid-1970 when the shortfall of petroleum and the products happened. ${ }^{3,4}$ It was mainly done to improve the soil stability but due to the absence of proper techniques and technologies, it did not flourish. In modern technologies with the high demand for infrastructure all around the world, soil stabilization was revived from the past. Copper slag (CS) and GGBS material is also used for the stabilization of soil..$^{5-7}$ Glass powder is also the waste material used for improving the soil stabilization. ${ }^{8}$ By using HYDRUS 1D model to determine the hydraulic conductivity of the soil for to determine the soil property. ${ }^{9}$ Better availability of research and development with the necessary equipment it has become more cost efficient and at the same time giving better results, Soil feasibility conditions for geotechnical projects are to have the following design criteria for construction such as design load, type of foundation and load-bearing capacity of the subsoil. The load carrying criteria of subsoil plays a major role in the construction which only leaves us with three options for changing the design or the soil or to abandon the site once and for all. The number of abandoned sites due to poor loadbearing capacity has increased in great numbers. ${ }^{10}$ This is where the soil stabilization namely in situ and ex-situ stabilization. The most simple soil stabilization process is draining and compaction 


\section{RASĀYAN J. Chem.}

Vol. 11 | No. 1 |111-117 | January - March | 2018

\section{EXPERIMENTAL}

\section{Experimental Procedure after Addition of Copper Slag to Clayey Soil}

Copper Slag is an Industrial by-product obtained in the production of copper extraction by smelting. The impurities which float on the metal are removed and is known as copper slag which is obtained in a molten state. This is a waste material in the industry. It is added in 10\%,20\%, and $30 \%$ in the clayey soil and various tests such as Optimum Moisture Content (OMC),Maximum Dry Density (MDD), Unconfined Compression Test(UCC) and California Bearing Ratio (CBR) is conducted and its various results obtained are tabulated and compared with that of the clayey soil as given in Table- 2 and the various test results of Clayey soil as shown in Table-1 .

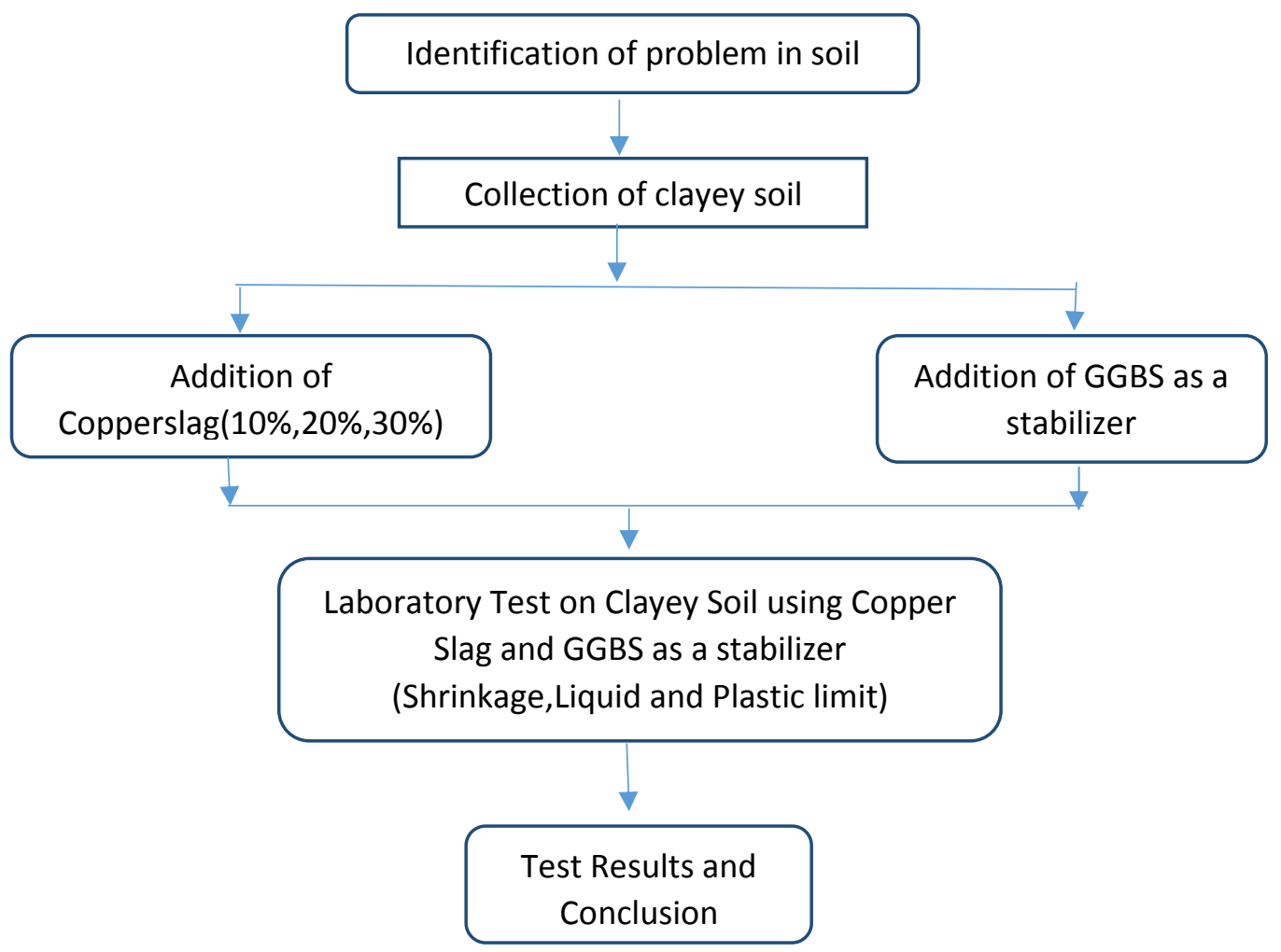

\section{Engineering Properties of Clayey Soil}

Scheme-1

Table-1: Various test results for Clayey Soil before adding Copper Slag

\begin{tabular}{c|c}
\hline Soil Properties & Results \\
\hline Specific Gravity & 2.56 \\
\hline Liquid Limit(\%) & 43.61 \\
\hline Plastic Limit(\%) & 19.39 \\
\hline Plasticity Index & 24.22 \\
\hline Shrinkage Limit(\%) & 15.73 \\
\hline Compaction Test(OMC) & 16.64 \\
\hline Compaction Test (Dry Density) $(\mathrm{g} / \mathrm{cc})$ & 1.68 \\
\hline Swelling (\%) & 58 \\
\hline UnconfinedCompression Test (UCC) $\left(\mathrm{kg} / \mathrm{cm}^{2}\right)$ & 1.2 \\
\hline
\end{tabular}

Table-2: Test Results after adding various \% of Copper Slag in Clayey Soil

\begin{tabular}{l|l|l|l|l}
\hline S.No. & Description & CopperSlag 10\% & CopperSlag 20\% & CopperSlag 30\% \\
\hline 1 & Shrinkage Limit(\%) & 13.87 & 11.59 & 9.15 \\
\hline 2 & Plasticity Index & 18.77 & 15.84 & 14.18 \\
\hline
\end{tabular}


RASĀYAN J. Chem.

Vol. 11 | No. 1 |111-117 | January - March | 2018

\begin{tabular}{l|l|l|l|l}
\hline 3 & Liquid Limit (\%) & 39.24 & 37.89 & 36.35 \\
\hline 4 & Plastic Limit (\%) & 20.47 & 22.05 & 22.17 \\
\hline
\end{tabular}

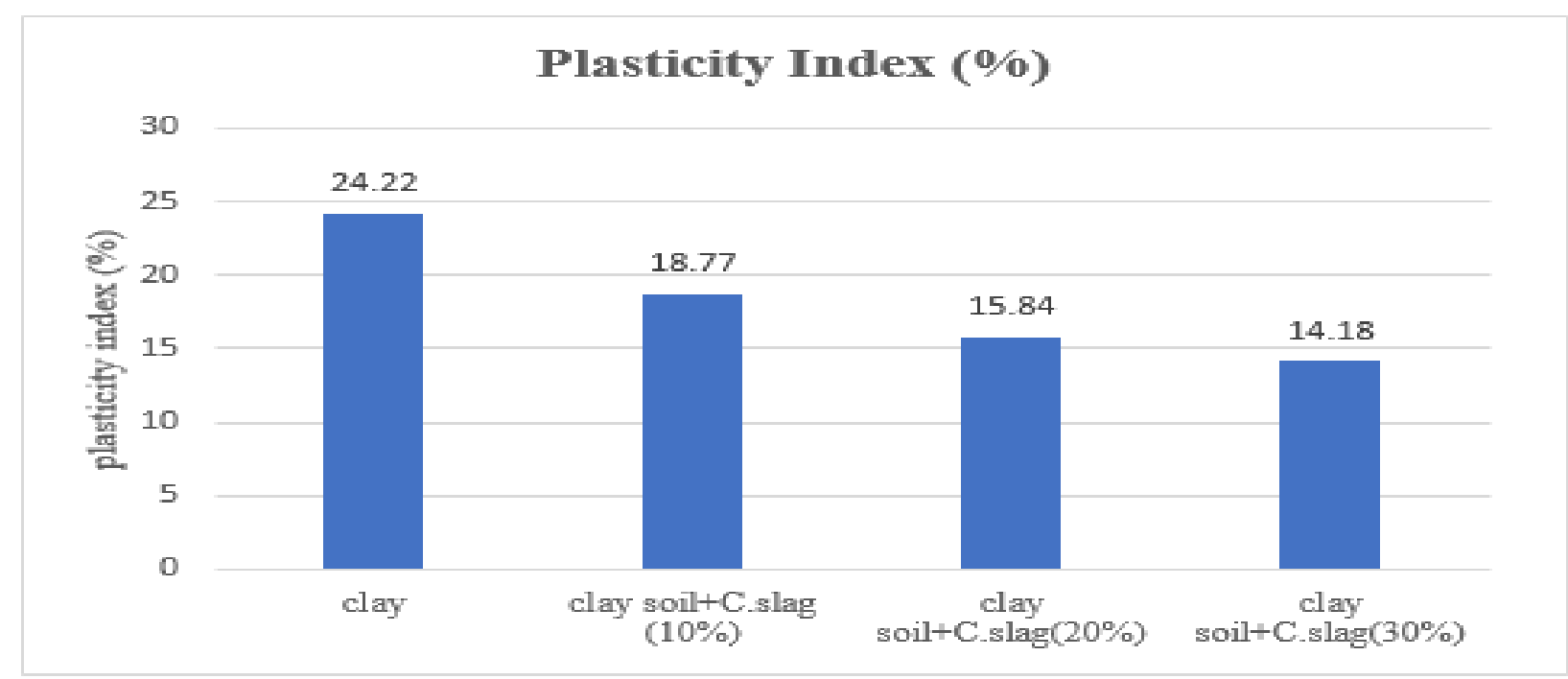

Fig.-1: Comparison of Plasticity Index of Clayey Soil and Copper Slag

Table-3: Comparison of OMC of Clayey Soil and Copper Slag

\begin{tabular}{c|c|c|c}
\hline \multirow{2}{*}{ S. No. } & Replacement Details & \multicolumn{2}{|c}{ Proctor Density } \\
\cline { 3 - 4 } & & OMC $(\%)$ & MDD $(\mathrm{g} / \mathrm{cc})$ \\
\hline 1 & Clay Soil + Copper Slag (10\%) & 15.08 & 1.74 \\
\hline 2 & Clay Soil + Copper Slag (20\%) & 13.77 & 1.79 \\
\hline 3 & Clay Soil + Copper Slag (30\%) & 12.53 & 1.82 \\
\hline
\end{tabular}

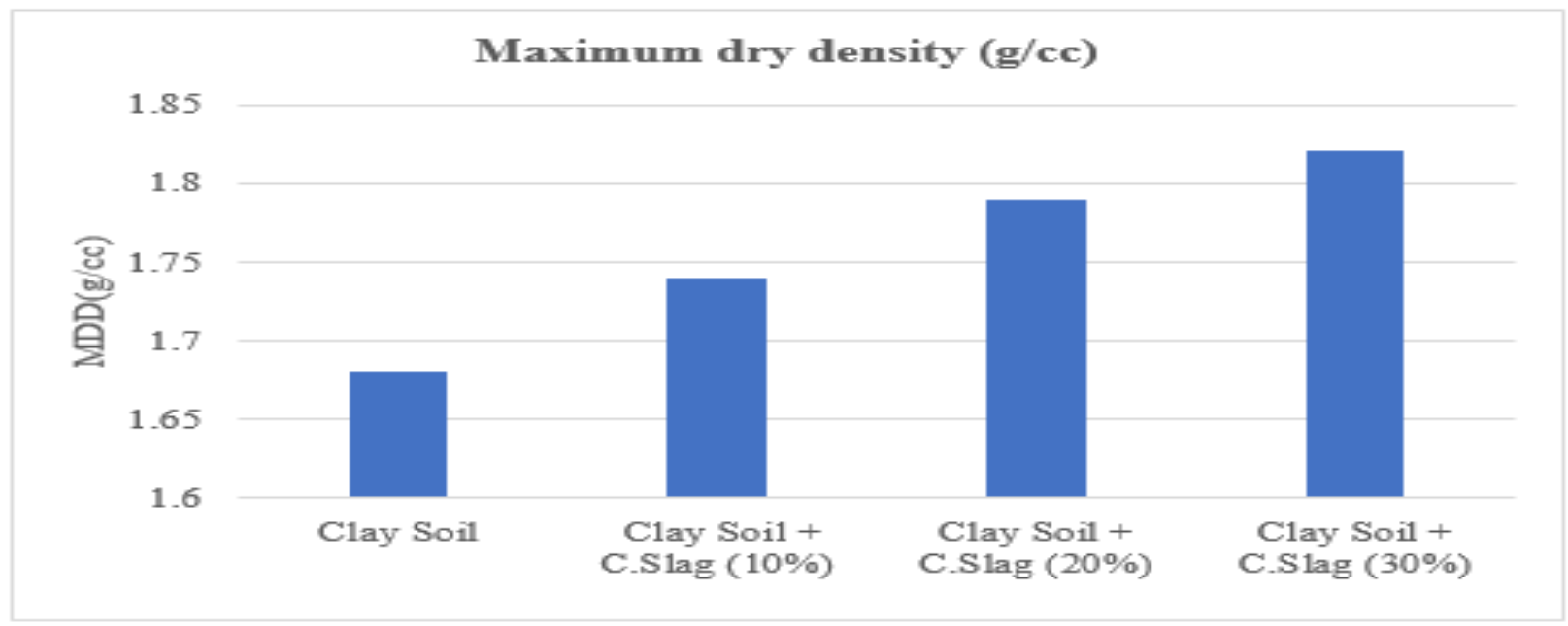

Fig.-2: Comparison of MDD of Clayey Soil and Copper Slag

Table-4: Comparison of UCT of Clayey Soil and Copper Slag

\begin{tabular}{c|c|c}
\hline S. No. & Replacement Details & Unconfined Compression Test (UCC) $\mathrm{kg} / \mathrm{cm}^{2}$ \\
\hline 1 & Clayey Soil + Copper Slag (10\%) & 1.8 \\
\hline 2 & Clayey Soil + Copper Slag (20\%) & 2.7 \\
\hline 3 & Clayey Soil + Copper Slag (30\%) & 3.5 \\
\hline
\end{tabular}


RASĀYAN J. Chem.

Vol. 11 | No. 1 |111-117 | January - March | 2018

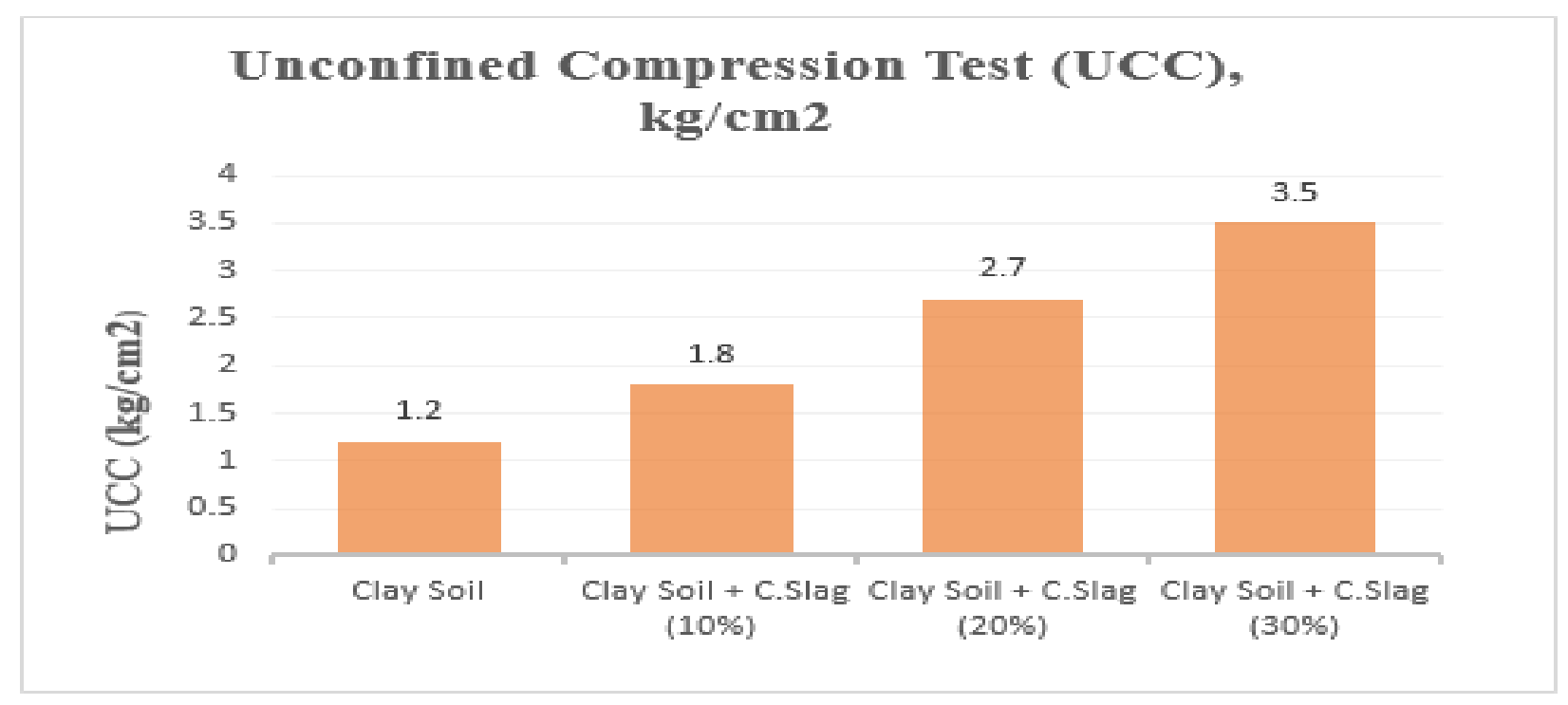

Fig.-3: Comparison of UCC for Clayey Soil and Copper Slag

Table-5: Comparison of CBR of Copper Slag and Clayey Soil

\begin{tabular}{c|c|c|c|c|c}
\hline \multirow{2}{*}{ S. No. } & Replacement Details & \multicolumn{2}{|c|}{ Unsoaked (\%) } & \multicolumn{2}{c}{ Soaked (\%) } \\
\cline { 3 - 5 } & & $\begin{array}{c}2.5 \mathrm{~mm} \\
\text { penetration }\end{array}$ & $\begin{array}{c}5.0 \mathrm{~mm} \\
\text { penetration }\end{array}$ & $\begin{array}{c}2.5 \mathrm{~mm} \\
\text { penetration }\end{array}$ & $\begin{array}{c}5.0 \mathrm{~mm} \\
\text { penetration }\end{array}$ \\
\hline 1 & Clayey Soil + Copper Slag (10\%) & 7.31 & 6.89 & 4.53 & 4.18 \\
\hline 2 & Clayey Soil + Copper Slag (20\%) & 9.47 & 9.21 & 7.72 & 7.06 \\
\hline 3 & Clayey Soil + Copper Slag (30\%) & 11.75 & 11.26 & 8.73 & 8.36 \\
\hline
\end{tabular}

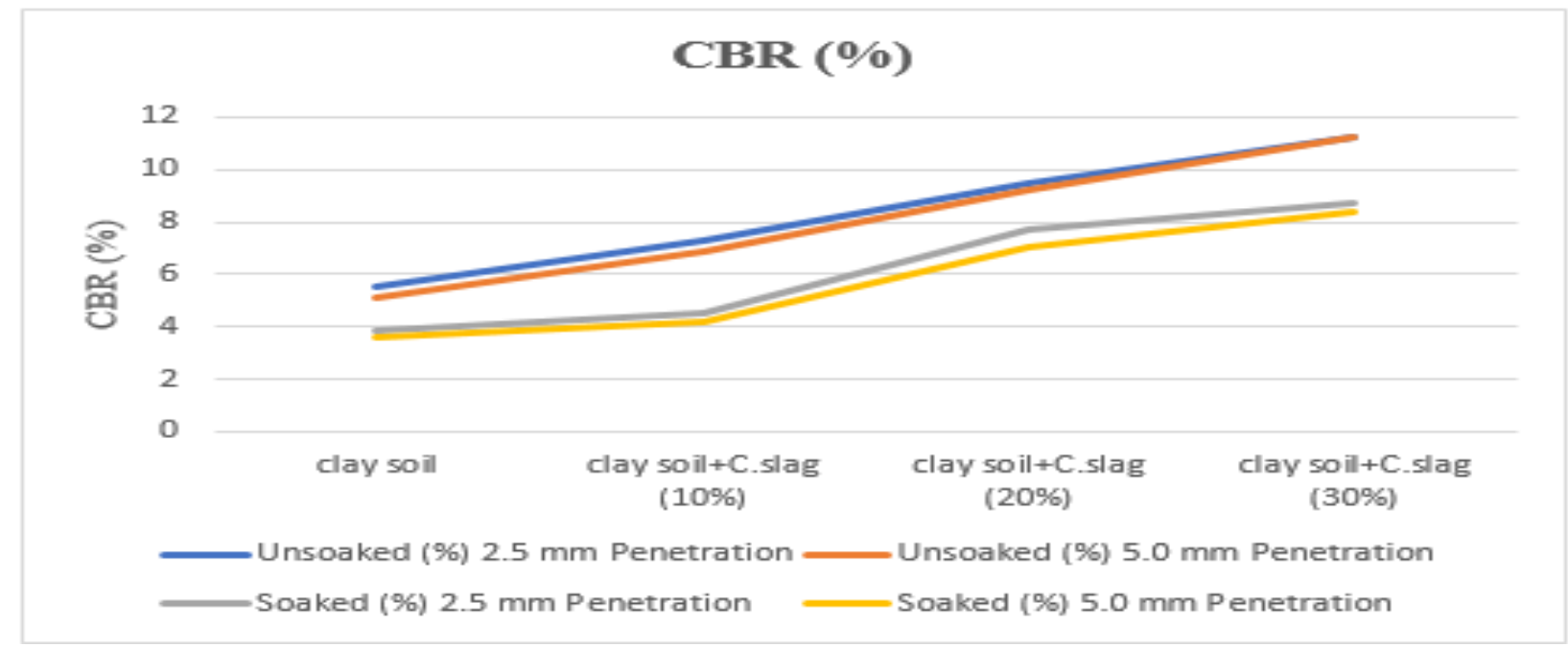

Fig.-4: Comparison of CBR for Clayey Soil and Copper Slag

Table-6: Test Results after adding various \% of GGBS in Clayey Soil

\begin{tabular}{c|c|c|c|c}
\hline S. No. & Description & GGBS (10\%) & GGBS (20\%) & GGBS (30\%) \\
\hline 1 & Shrinkage Limit (\%) & 15.53 & 13.59 & 12.15 \\
\hline 2 & Plasticity Index & 18.00 & 12.33 & 9.38 \\
\hline 3 & Liquid Limit & 38.00 & 37.50 & 35.70 \\
\hline 4 & Plastic Limit (\%) & 20.00 & 25.17 & 26.32 \\
\hline
\end{tabular}


RASĀYAN J. Chem.

Vol. 11 | No. 1 |111-117 | January - March | 2018

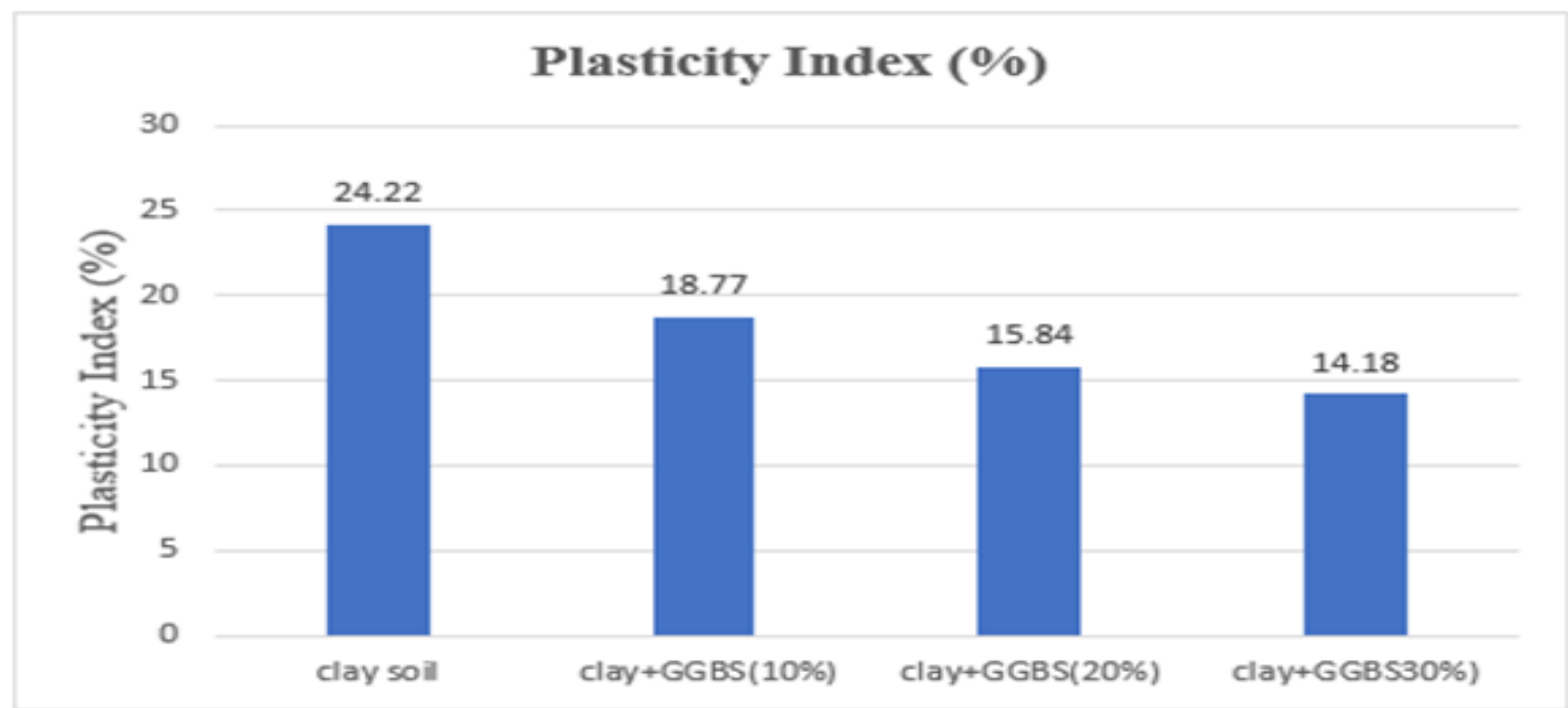

Fig.-5: Comparison of Plasticity Index for Clayey Soil and GGBS

Table-7: OMC values after adding various \% of GGBS with Clay Soil

\begin{tabular}{c|c|c|c}
\hline S. No. & Replacement Details & \multicolumn{2}{|c}{ Proctor Density } \\
\cline { 3 - 4 } & & OMC (\%) & MDD (\%) \\
\hline 1 & Clayey Soil + GGBS (10\%) & 14.23 & 1.74 \\
\hline 2 & Clayey Soil + GGBS (20\%) & 13.25 & 1.80 \\
\hline 3 & Clayey Soil + GGBS (30\%) & 11.63 & 1.86 \\
\hline
\end{tabular}

\section{dry density (g/cc)}

1.9

1.85

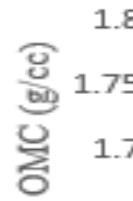

1.65

1.6

1.55

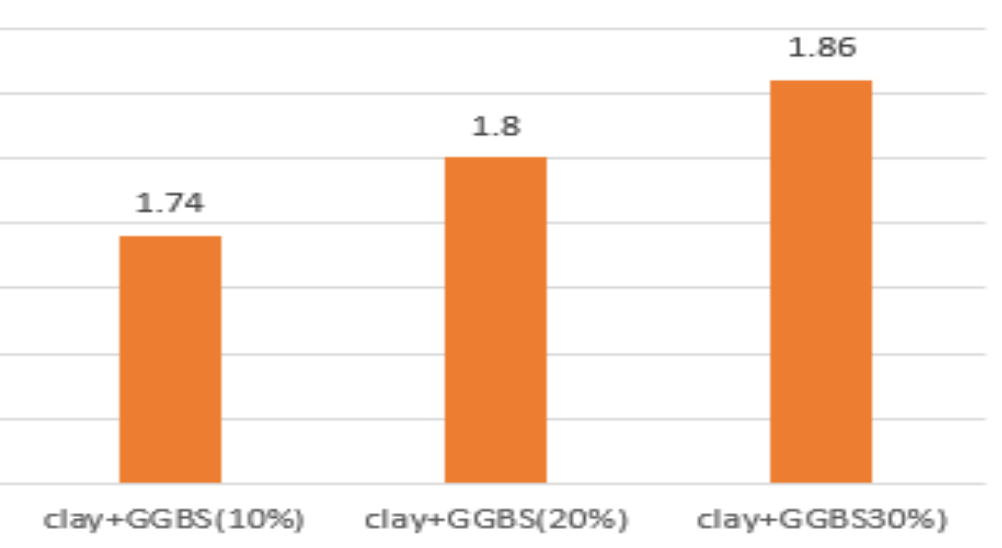

clay soil

GBS30\%)

Fig.-6: Comparison of MDD for Clayey soil and GGBS

Table: 8 UCC values after adding various \% of GGBS with Clay Soil

\begin{tabular}{c|c|c}
\hline S. No. & Replacement Details & Unconfined Compression Test (UCC) $\mathrm{kg} / \mathrm{cm}^{2}$ \\
\hline 1 & Clayey Soil + GGBS (10\%) & 1.4 \\
\hline 2 & Clayey Soil + GGBS (20\%) & 2.3 \\
\hline 3 & Clayey Soil + GGBS (30\%) & 3.3 \\
\hline
\end{tabular}


RASĀYAN J. Chem.

Vol. 11 | No. 1 |111-117 | January - March | 2018

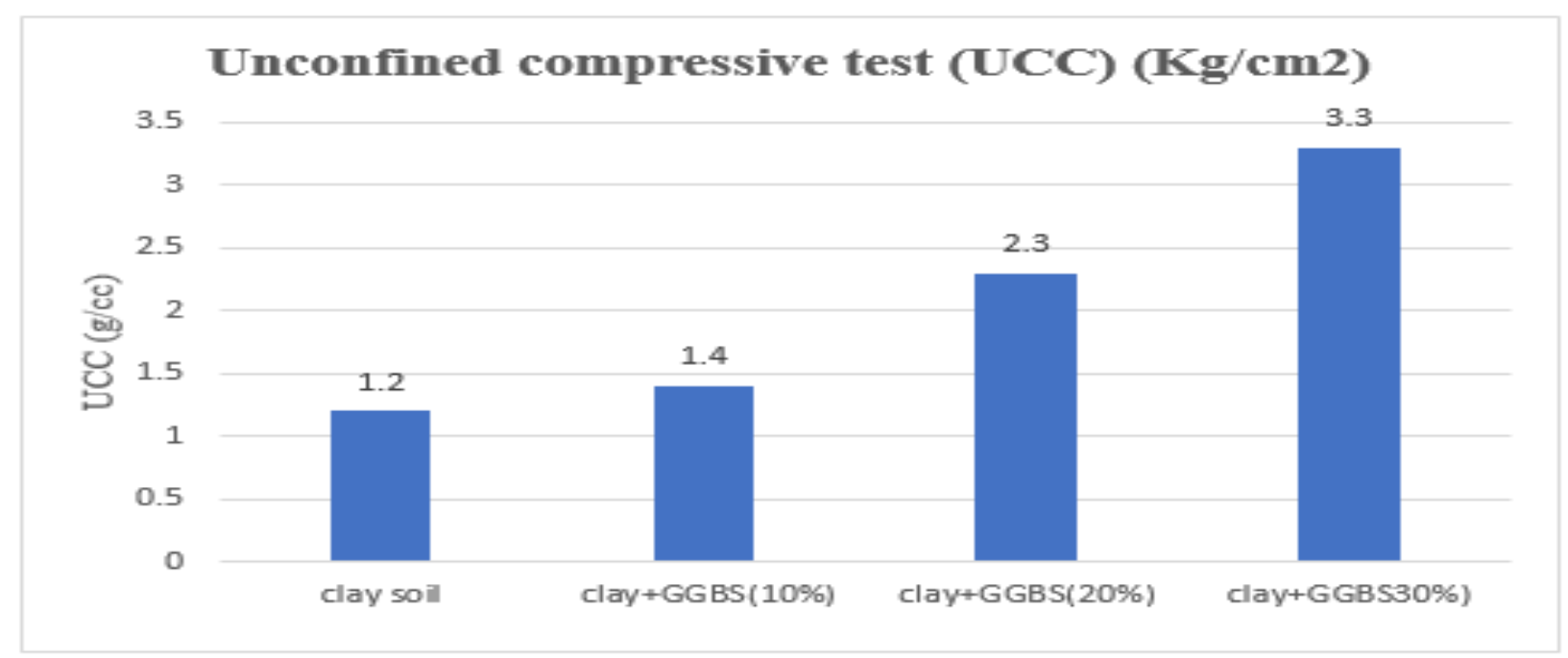

Fig.-7: Comparison of UCC for Clayey soil and GGBS

Table-9: CBR values after adding various $\%$ of GGBS with Clay Soil

\begin{tabular}{c|c|c|c|c|c}
\hline \multirow{2}{*}{ S. No. } & Replacement Details & \multicolumn{2}{|c|}{ Unsoaked (\%) } & \multicolumn{2}{c}{ Soaked (\%) } \\
\cline { 3 - 6 } & & $\begin{array}{c}2.5 \mathrm{~mm} \\
\text { Penetration }\end{array}$ & $\begin{array}{c}5.0 \mathrm{~mm} \\
\text { Penetration }\end{array}$ & $\begin{array}{c}2.5 \mathrm{~mm} \\
\text { Penetration }\end{array}$ & $\begin{array}{c}5.0 \mathrm{~mm} \\
\text { Penetration }\end{array}$ \\
\hline 1 & Clayey Soil + GGBS (10\%) & 5.74 & 5.31 & 3.93 & 3.23 \\
\hline 2 & Clayey Soil + GGBS (20\%) & 9.13 & 8.89 & 5.10 & 4.70 \\
\hline 3 & Clayey Soil + GGBS (30\%) & 8.26 & 7.91 & 4.87 & 4.58 \\
\hline
\end{tabular}

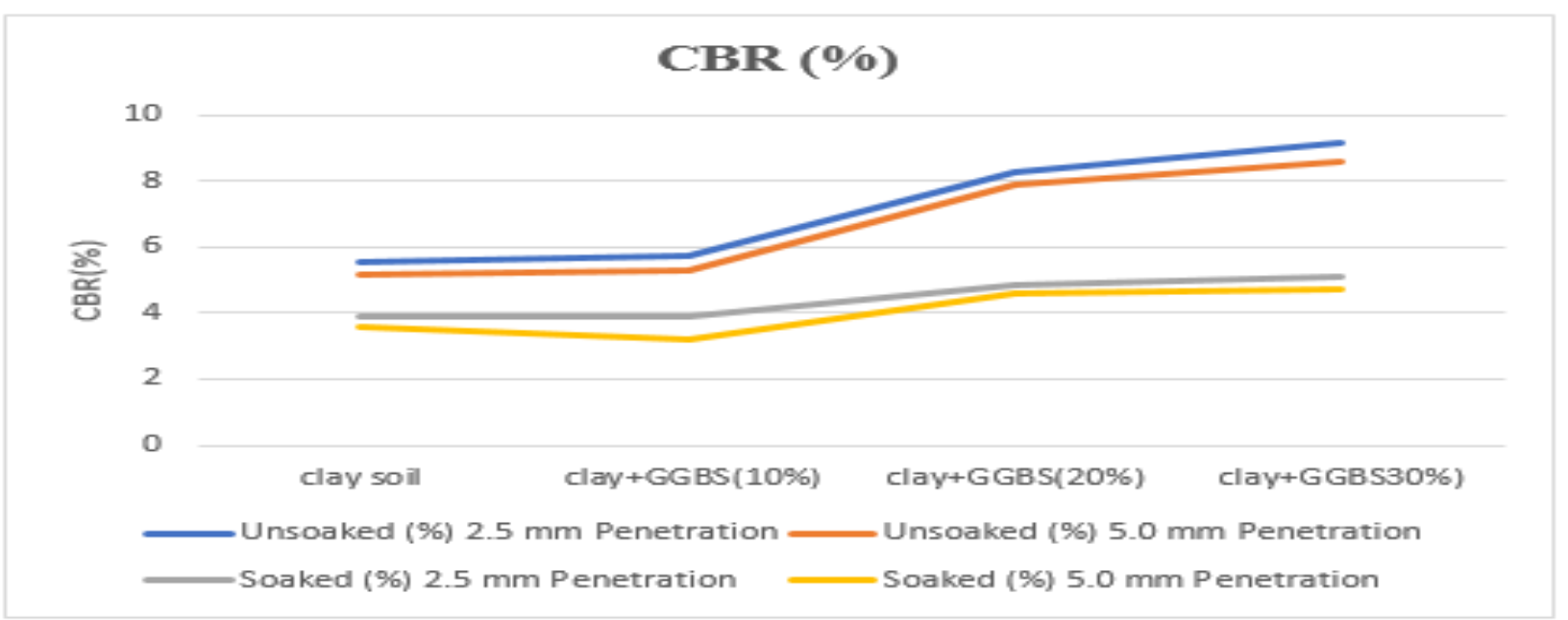

Fig.-8: Comparison of CBR for Clayey soil and GGBS

\section{Inference of Copper Slag with Clayey Soil Atterberg Limit}

It is observed that the liquid Limit,Shrinkage Limit,Plasticity Index for the Copper Slag mix sample of $10 \%$ is higher when compared to other two percentage mix.Plastic Limit for Copper Slag content of 30\% is higher than other two percentage mix as shown in Table-2 and Fig.-1.

\section{Optimum Moisture Content}

OMC and MDD of the Clayey soil with the addition of Copper slag as a stabilizer.Table-3 and Fig.-2 represent, it is observed that the mix proportion of $30 \%$ has less moisture content and high dry density. 
RASĀYAN J. Chem.

Vol. 11 | No. 1 |111-117 | January - March | 2018

\section{Unconfined Compression Test}

Table-4 and Fig.-3 observed that the UCT value of clay soil sample with Copper Slag of $30 \%$ has attended high strength when compared to other two proportions.

\section{California Bearing Ratio Test}

The CBR of Clayey Soil sample with copper slag of $30 \%$ showed good results when compared to all other proportions shown in Table-5 and Fig.-4.

\section{Inference of Clayey Soil with GGBS Atterberg Limit}

The Atterberg Limit of Clayey soil by using Ground Granulated Blast Furnace Slag as a stabilizer with mix proportion of $10 \%$ showed good results than $20 \%$ and $30 \%$ shown in Table- 6 and Fig.-5.

\section{Optimum Moisture Content}

Table-7 and Fig. 6 are observed that the clayey soil with GGBS of 305 showed less moisture Content and high dry density.

\section{Unconfined Compression Test}

The Unconfined Compression Test Table- 8 and Fig.-7 shows that the clay soil with GGBS with $30 \%$ have attended high compression strength of $3.3 \mathrm{~kg} / \mathrm{cm}^{3}$

\section{California Bearing Ratio Test}

Table-9 and Fig.-8 observed that the clay soil with ground granulated blast furnace slag of $20 \%$ showed good result than other two mix percentage.

\section{CONCLUSION}

It can be concluded from the above study that a notable amount of improvement can be seen in the moisture content and maximum dry density in the soil treated with Copper Slag and GGBS. Cost wise, admixtures (less costly) reduces the amount of copper slag and GGBS, making it needed in smaller quantities to make the soil non-plastic. It is found that the addition of copper slag and GGBS mix to sub base increasing the unconfined compressive strength value more than ordinary methods, thereby reducing the ground improvement costs.

\section{REFERENCES}

1. Mandeep Singh and Anupam Mittal, International Journal of Engineering Research and Applications, 2(5), 1(2014).

2. Ankit Singh Negi, Mohammed Faizan, Devashish Pandey Siddharth and Rehanjot Singh, International Journal of Innovative Research in Science, Engineering and Technology, 2(2), 1(2014).

3. Mukesh Patel and H. S. Patel, Civil and Environmental Research, 2(4), 6 (2012)

4. P. Mohanraj, G. Muthupandi and K. Naveenkumar, Southasian Journal of Engineering and Technology,3(7), 12 (2017)

5. Godavarthi V. L. N. Murthi, Atkuri Venkata Krishna, Vedula V. N. Prabhakar Rao, In Proceedings of the 1st GeoMEast International Congress and Exhibition on Sustainable Civil Infrastructures,Egypt,pp.337-348 (2017)

6. B. Rajendra, Siva Gopi. K, Hanumantha Rao, International Journal of Civil Engineering and Technology, 8(4), 1985 (2017)

7. Ch. Ravitej and D. S. V. Prasad, International Journal of Scientific Research in Science and Technology, 3(3), 2395 (2017)

8. R. Nirmala and M. Shanmugapriya, International Journal of Chemical Sciences, 15(1),1( 2017)

9. M. Kavisri, International Journal of Applied Engineering Research,10(6),14529 (2015)

10. M. S. Dixit and K. A. Patel, In proceedings of Indian Geotechnical Conference, Guntur, pp.682-685 (2010)

[RJC-1805/2017] 